\title{
Radon, water chemistry and pollution check by volatile organic compounds in springs around Popocatepetl volcano, Mexico
}

\author{
Nuria Segovia $\left({ }^{1}\right)$, Pablo Peña $\left({ }^{2}\right)$, Carlos Valdés $\left({ }^{1}\right)$, María Aurora Armienta $\left({ }^{1}\right)$, \\ Beatriz Lopez $\left({ }^{2}\right)$, Guadalupe Cisniega $\left({ }^{2}\right)$ and Manuel Mena $\left({ }^{1}\right)$ \\ $\left.{ }^{(}\right)$Instituto de Geofisica, Universidad Nacional Autónoma de Mexico (UNAM), México D.F., México \\ ${ }^{(}{ }^{2}$ Instituto Nacional de Investigaciones Nucleares (ININ), México D.F., México
}

\begin{abstract}
Popocatepetl volcano is a high-risk active volcano in Central Mexico where the highest population density in the country is settled. Radon in the soil and groundwater together with water chemistry from samples of nearby springs were analysed as a function of the 2002-2003 volcanic activity. The measurements of soil radon indicated fluctuations related to both the meteorological and sporadic explosive events. Groundwater radon showed essential differences in concentration due to the specific characteristics of the studied springs. Water chemistry showed also stability along the monitoring period. No anthropogenic pollution from Volatile Organic Compounds (VOCs) was observed. An overview of the soil radon behaviour as a function of the volcanic activity in the period 1994-2002 is also discussed.
\end{abstract}

Key words soil radon - water chemistry - volcanic activity - Mexico

\section{Introduction}

Popocatepetl $\left(19^{\circ} \mathrm{N} ; 99^{\circ} \mathrm{W} ; 5426 \mathrm{~m}\right.$ altitude $)$ is a high-risk active volcano due essentially to its geographical location in Central Mexico and its eruptive history. It is located in a region marked by the highest population density in the country, $60 \mathrm{~km}$ from Mexico City, one of the largest cities in the world. The eruptive history of Popocatepetl has been documented since 1347. In 1519 an eruptive stage lasted until 1530 . In the 20th century multiple eruptive events occurred between 1920 and 1927,

Mailing address: Dr. Nuria Segovia, Instituto de Geofisica, Universidad Nacional Autónoma de Mexico (UNAM), Ciudad Universitaria, 04510 México D.F., México; e-mail: nurina@terra.com.mx having an explosive character of moderate magnitude (De la Cruz-Reyna et al., 1995; CENAPRED, 2003). In December, 1994, an eruptive phase started showing stages of different volcanic activity along the last eight years. During this period, the volcano has been subject to intensive studies of radon, seismicity, ejecta composition, etc. (Varley and Armienta, 1999, 2001; Segovia et al., 2001, 2002). The main purpose of this paper is to analyse the effects of the recent volcanic activity (20022003) on soil and groundwater radon and the chemical composition of groundwater. An overall compilation of the volcanic seismicity and the soil radon behaviour from 1994 until 2002 is also shown.

\section{Experimental approach}

\subsection{The volcano activity 2002-2003}

From February, 2002, to February, 2003, the Popocatepetl activity showed an interesting vari- 
ation characterised by periods of intense seismic activity of short duration. These were occasionally accompanied by the formation of small lava accumulation inside the volcano crater known as lava domes (January 24th, February 19th and April 29th 2002). During other episodes (May 14th, July 23rd and August 15-17th 2002) lava dome formation did not accompany the increase in seismic activity. The dome formation resumed on September 17th and on December 2nd 2002, with a lava dome $40 \mathrm{~m}$ tall and $180 \mathrm{~m}$ radius. From February 4th to the 23rd 2003, intensive volcanic activity was recorded, marking a signif- icant stage of eruptions, where 13 volcanic explosions destroyed the domes formed during 2002. Some of these explosions generated ash clouds of more than $4 \mathrm{~km}$ in height, which were transported NE to Florida and detected by the GOES satellite.

\subsection{Monitoring sites}

Soil radon monitoring was performed at two fixed stations: Tlamacas (4000 $\mathrm{m}$ altitude and in a distance $4.7 \mathrm{~km}$ from the crater) and Paso de

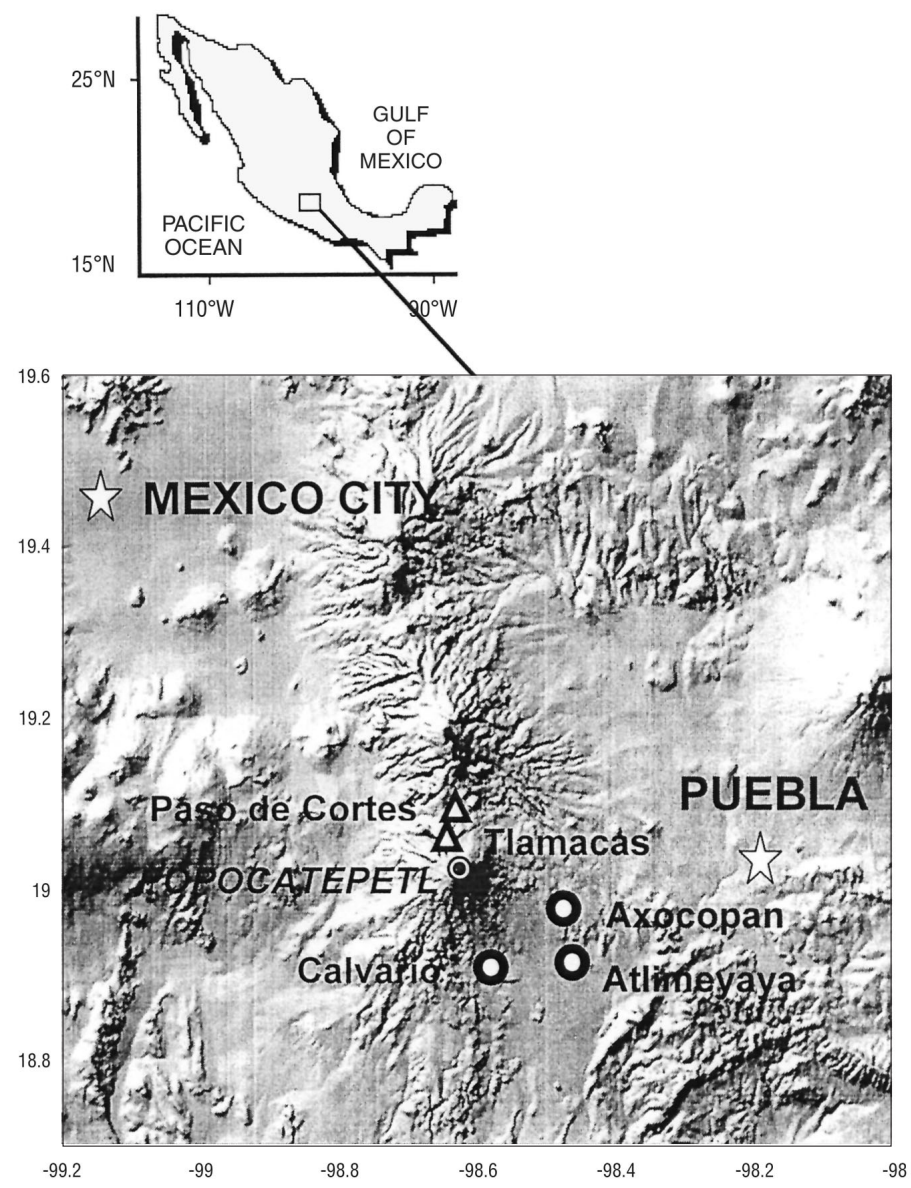

Fig. 1. Location of Popocatepetl volcano between Mexico City and Puebla valleys in Central Mexico. The soil radon monitoring stations (Paso de Cortes and Tlamacas) and the three monitored springs (Axocopan, Atlimeyaya and Calvario) are also shown. 
Cortes $(3400 \mathrm{~m}$ altitude and in a distance $7.5 \mathrm{~km}$ from the crater). Three springs, Atlimeyaya, Axocopan and Calvario, located at the southern flank of the volcano (at altitudes of $2200 \mathrm{~m}, 1950$ $\mathrm{m}$ and $2300 \mathrm{~m}$ respectively), were systematically monitored during this period recording radon and major chemical compounds (fig. 1). Anthropogenic volatile organic compounds (VOCs) were also studied in the water samples in order to determine possible contamination paths.

\subsection{Measuring techniques}

Long term soil radon determination $(70 \mathrm{~cm}$ depth) was performed with Solid State Nuclear Track Detectors (SSNTD), LR 115 type II, from Dosirad Co. France. The detailed methodology was reported by Segovia et al. (2002). The water samples were analysed for dissolved radon with a Packard TRI-CARB 2700TR liquid scintillation detection system and with an Alphaguard system from Genitron Instruments. The liquid scintillation method implies the radon extraction in toluene, while the Alphaguard system consists of a ionisation chamber where air is bubbled to extract radon from the sample.

In the field, electrical conductivity, temperature and $\mathrm{pH}$-values of the spring waters were also determined. Chemical analyses were performed by standard methods, as given in APHA-AWWAWPCF (1995). The ionic charge balance confirmed the accuracy of the analyses. VOCs identification was performed with a Tekmar ${ }^{\mathrm{TM}} 3000$ (GC-MS) equipment using the EPA method 524.2. For the majority of the VOCs, the detection limit of the method ranges between 0.01 to $0.09 \mu \mathrm{gL}^{-1}$ (Cisniega et al., 2002).

\section{Results and discussions}

Soil radon at Tlamacas and Paso de Cortes (fig. 2a), showed significant differences between the two monitoring stations. The soil radon values at Tlamacas showed peaks in February and April, 2002, during the period of lava dome formation. Afterwards the radon concentration values decreased during the rainy season, between June and October, and smoothly increased from November,
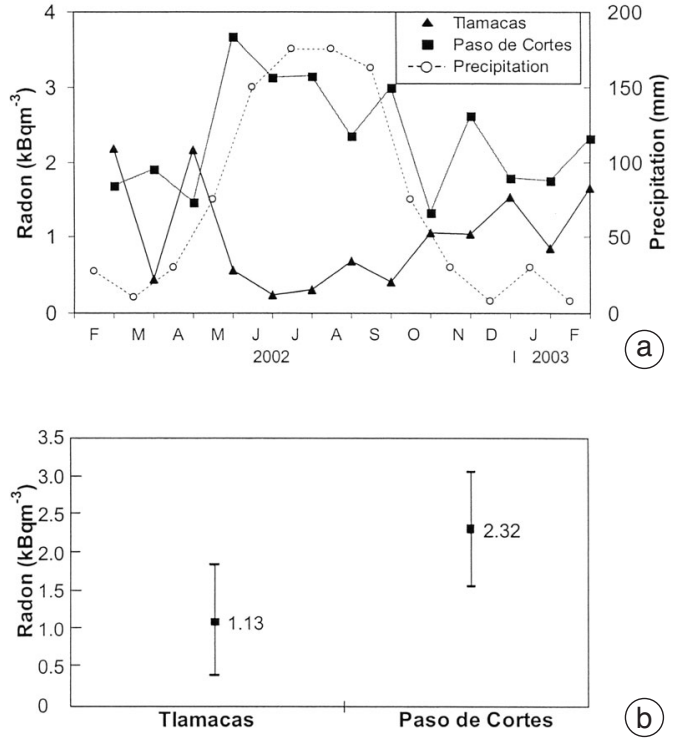

Fig. 2a,b. a) Soil radon concentration values $\left(\mathrm{kBqm}^{-3}\right)$ and precipitation $(\mathrm{mm})$ from February, 2002, until February, 2003, at the monitoring stations Paso de Cortes and Tlamacas. b) The average and standard deviation of radon data at the two monitoring stations.

2002, until February, 2003, linked with the activity of this last month. On the contrary, at Paso de Cortes, higher values corresponded to the rainy season. At this site, no effect on the soil radon concentration was observed linked with the dome formation at the beginning of 2002. However, radon peaks occurred in September and November, 2002, probably related to the dome formation in September and December. At the end of February, 2003, the soil radon at Paso de Cortes and Tlamacas showed similar patterns.

The average soil radon concentration values were low at both stations (fig. 2b). However the values at Paso de Cortes were twice as high as those at Tlamacas. The differences in the soil radon behaviour and in average concentration values, are probably related to the specific soil characteristics at each station. Tlamacas is located at the cinder cone with scarce vegetation whereas $\mathrm{Pa}$ so de Cortes is set in the forest, having an organic rich top soil of up to $70 \mathrm{~cm}$ in thickness, and differences in the soil gases evolution are expected. 
The groundwater radon measured by the two methods, liquid scintillation and ionisation chamber (Alphaguard), showed differences, but the general results were characterised by a correlation factor of 0.8 (fig. 3). This can be considered a reasonable approximation as the two methods of radon extraction have considerable

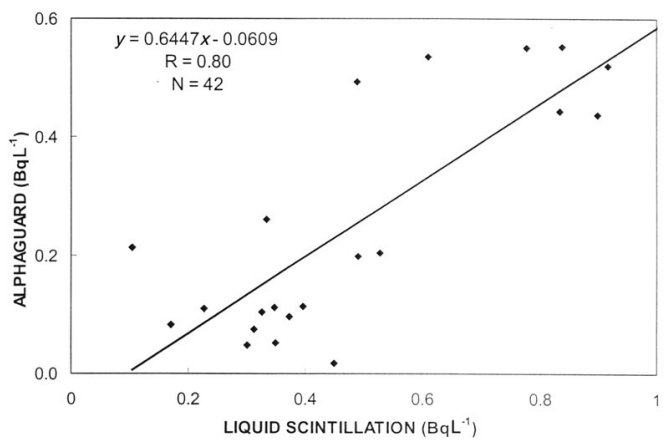

Fig. 3. Plot of groundwater radon data $\left(\mathrm{BqL}^{-1}\right)$ obtained by the liquid scintillation versus Alphaguard methods. Best fitting line indicates a correlation factor of 0.8 .
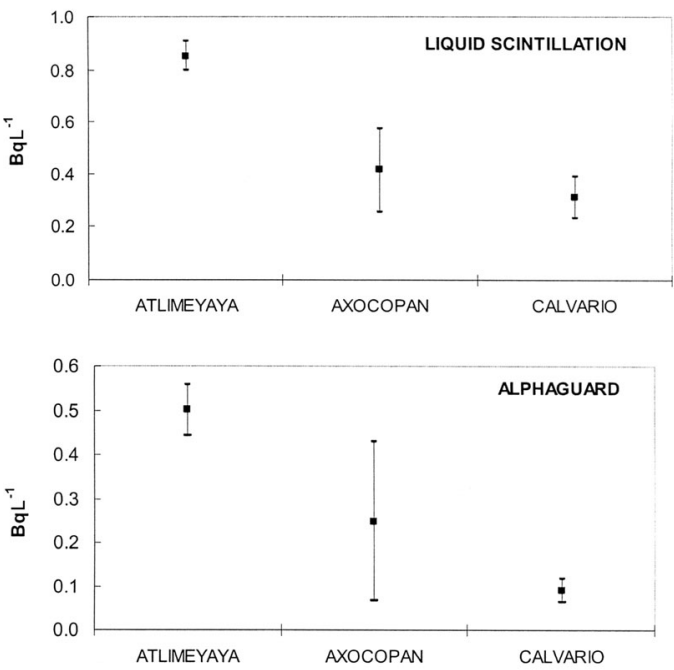

Fig. 4. Average and standard deviation of groundwater radon values obtained with the two methods (liquid scintillation and Alphaguard) at the three springs (Atlimeyaya, Axocopan and Calvario). differences. The average groundwater radon values obtained at the three springs with the two methods, showed different values for each one of the springs (fig. 4). The highest fluctuations in the radon concentration were observed at Axocopan, but no link was observed between the groundwater radon fluctuations and the different stages of the volcanic activity during 2002-2003.

The water chemistry of Atlimeyaya, Axocopan and Calvario springs (table I and fig. 5) shows low variations for each site and indicates a higher mineralization in Axocopan as compared with the two other springs. Axocopan has the lowest altitude and the higher temperature of the three studied springs. However, since the chemical fluctuations in the present period of study have been so low, no correlation with the volcanic activity could be observed. Volcanic gases emanating from the eruptive stage do not seem to had affected the surrounding aquifers.

The analyses of the presence of Volatile Organic Compounds (VOCs) in the water samples were performed due to a possible anthropogenic pollution since the sampled springs are utilised for domestic and industrial use. In rural areas, the occurrence of VOCs in surface and groundwaters can originate from solvents, gasoline, aromatic hydrocarbons, herbicides and pesticides (Cisniega et al., 2002). The results of the study showed that VOCs were below the detection limit of the method.

An overall compilation of the volcanic activity and the soil radon evolution at Popocatepetl volcano along the period from the beginning of the eruptive stage in 1994, until 2003, is shown in fig. 6a-e. Panels a and b show soil radon concentration values, in $\mathrm{kBqm}^{-3}$, at Tlamacas and Paso de Cortes respectively. Panel c, shows the seismic energy measured as a cumulative measurement of the continuous ground vibration (solid line) and the cumulative energy released by the volcano-tectonic earthquakes (dashed line). The letters «d» and «D» at the bottom of this panel correspond to the formation of small $\left(\leq 1.5 \times 10^{6} \mathrm{~m}^{3}\right)$ and large $\left(\geq 1.5 \times 10^{6} \mathrm{~m}^{3}\right)$ lava domes, inside the Popocatepetl volcano crater. The large energy step observed at the end of 2000 , corresponds to the largest volcanic activity between 1994 and 2002. The vertical dashed lines represent different stages of volcanic activ- 
Table I. Chemical composition of spring samples from Atlimeyaya, Axocopan and Calvario, from January, 2002, to May, 2003. Concentration values in $\mathrm{mgL}^{-1}$, temperature in ${ }^{\circ} \mathrm{C}$ and conductivity $(\Lambda)$ in $\mu \mathrm{Scm}^{-1}$.

\begin{tabular}{|c|c|c|c|c|c|c|c|c|c|c|c|c|}
\hline Date & $\mathrm{Ca}^{2+}$ & $\mathrm{Mg}^{2+}$ & $\mathrm{Na}^{+}$ & $\mathrm{K}^{+}$ & $\mathrm{Cl}^{-}$ & $\mathrm{SO}_{4}^{2-}$ & $\mathrm{HCO}_{3}^{-}$ & $\mathrm{F}^{-}$ & $\mathrm{SiO}_{2}$ & $T^{\circ} \mathrm{C}$ & $p H$ & $\Lambda$ \\
\hline \multicolumn{13}{|l|}{ Atlimeyaya } \\
\hline 16.01 .2002 & 10.6 & 8.4 & 16.1 & 2.6 & 2.9 & 7.5 & 97.6 & 0.6 & 59.1 & 14.0 & 6.6 & 185.0 \\
\hline 13.02.2002 & 10.7 & 8.0 & 15.8 & 2.7 & 3.7 & 8.9 & 97.6 & 0.5 & 68.8 & 14.0 & 6.5 & 183.0 \\
\hline 13.03 .2002 & 11.5 & 8.2 & 16.5 & 2.8 & 1.9 & 6.2 & 97.4 & 0.5 & 56.7 & 16.0 & 6.5 & 180.0 \\
\hline 17.04.2002 & 12.0 & 8.5 & 16.6 & 2.6 & 2.9 & 6.2 & 97.4 & 0.5 & 67.4 & 17.0 & 6.3 & 182.0 \\
\hline 15.05 .2002 & 12.1 & 8.6 & 17.0 & 2.3 & 2.9 & 6.3 & 96.6 & 0.5 & 53.7 & 15.0 & 6.5 & 185.0 \\
\hline 13.06 .2002 & 10.7 & 7.5 & 15.3 & 2.5 & 2.6 & 6.5 & 99.1 & 0.5 & 60.6 & 14.0 & 6.5 & 173.0 \\
\hline 11.12 .2002 & 13.5 & 6.1 & 16.5 & 2.7 & 3.4 & 6.3 & 99.0 & 0.6 & 62.8 & 13.0 & 6.6 & 178.0 \\
\hline 15.01 .2003 & 10.0 & 8.5 & 14.8 & 2.7 & 3.6 & 6.0 & 97.1 & 0.5 & 61.6 & 13.0 & 6.4 & 180.0 \\
\hline 10.02 .2003 & 13.0 & 6.6 & 14.7 & 2.6 & 3.8 & 6.7 & 94.9 & 0.5 & 56.4 & 16.0 & 6.6 & 180.0 \\
\hline 12.03.2003 & 11.7 & 6.1 & 15.9 & 2.6 & 3.1 & 7.2 & 103.1 & 0.6 & 49.7 & 16.0 & 6.5 & 180.0 \\
\hline 09.04 .2003 & 12.3 & 5.2 & 15.5 & 2.6 & 4.0 & 7.0 & 96.9 & 0.6 & 55.5 & 14.0 & 6.7 & 180.0 \\
\hline 17.05 .2003 & 10.8 & 7.5 & 15.5 & 2.7 & 3.0 & 10.2 & 96.4 & 0.6 & 58.7 & 14.7 & 6.5 & 180.0 \\
\hline Average & 11.6 & 7.4 & 15.8 & 2.6 & 3.1 & 7.1 & 97.8 & 0.6 & 59.2 & 14.7 & 6.5 & 180.5 \\
\hline$\sigma$ & 1.1 & 1.1 & 0.7 & 0.1 & 0.6 & 1.3 & 2.0 & 0.0 & 5.5 & 1.3 & 0.1 & 3.2 \\
\hline \multicolumn{13}{|l|}{ Axocopan } \\
\hline 16.01 .2002 & 34.8 & 44.4 & 57.7 & 6.4 & 20.8 & 41.6 & 405.8 & 0.6 & 89.9 & 21.0 & 6.1 & 747.0 \\
\hline 13.02.2002 & 33.8 & 44.3 & 59.6 & 6.8 & 19.5 & 38.6 & 406.7 & 0.5 & 90.1 & 21.0 & 6.1 & 714.0 \\
\hline 13.03 .2002 & 34.1 & 45.0 & 60.2 & 6.2 & 14.1 & 44.6 & 407.9 & 0.5 & 90.3 & 21.0 & 6.9 & 668.0 \\
\hline 17.04 .2002 & 35.1 & 44.4 & 60.9 & 6.3 & 16.0 & 39.2 & 409.9 & 0.5 & 90.1 & 23.0 & 6.1 & 678.0 \\
\hline 15.05 .2002 & 34.7 & 44.9 & 62.5 & 7.4 & 18.5 & 40.8 & 403.8 & 0.5 & 81.7 & 20.0 & 5.9 & 726.0 \\
\hline 13.06 .2002 & 35.7 & 42.6 & 56.2 & 6.3 & 17.6 & 40.8 & 403.8 & 0.5 & 91.4 & 20.0 & 6.0 & 704.0 \\
\hline 11.12.2002 & 36.9 & 45.7 & 61.5 & 6.5 & 17.3 & 39.7 & 409.7 & 0.6 & 95.2 & 16.0 & 6.0 & 708.0 \\
\hline 15.01 .2003 & 35.5 & 41.8 & 55.4 & 6.3 & 16.6 & 38.5 & 409.4 & 0.4 & 93.5 & 18.0 & 6.3 & 714.0 \\
\hline 10.02 .2003 & 35.4 & 43.6 & 53.4 & 5.9 & 16.6 & 39.6 & 405.0 & 0.6 & 85.6 & 18.0 & 6.3 & 710.0 \\
\hline 12.03 .2003 & 35.4 & 42.8 & 57.3 & 6.1 & 18.5 & 39.1 & 412.6 & 0.6 & 75.9 & 18.0 & 6.5 & 700.0 \\
\hline 09.04 .2003 & 36.8 & 42.2 & 56.9 & 6.0 & 19.7 & 41.4 & 412.4 & 0.6 & 85.4 & 21.0 & 6.0 & 714.0 \\
\hline 17.05 .2003 & 35.1 & 42.1 & 58.0 & 6.4 & 17.5 & 44.5 & 409.0 & 0.5 & 85.4 & 20.0 & 6.0 & 716.0 \\
\hline Average & 35.3 & 43.6 & 58.3 & 6.4 & 17.7 & 40.7 & 408.0 & 0.5 & 87.8 & 19.8 & 6.2 & 708.3 \\
\hline$\sigma$ & 0.9 & 1.3 & 2.7 & 0.4 & 1.8 & 2.1 & 3.0 & 0.0 & 5.4 & 1.9 & 0.3 & 20.5 \\
\hline \multicolumn{13}{|l|}{ Calvario } \\
\hline 16.01 .2002 & 9.0 & 9.4 & 12.7 & 2.2 & 3.3 & 24.7 & 69.3 & 0.4 & 66.8 & 17.0 & 7.0 & 182.0 \\
\hline 13.02.2002 & 8.8 & 9.6 & 12.7 & 2.3 & 4.0 & 24.8 & 70.5 & 0.4 & 77.0 & 16.0 & 6.7 & 178.0 \\
\hline 13.03 .2002 & 9.0 & 10.3 & 13.0 & 2.3 & 2.2 & 22.3 & 69.7 & 0.4 & 64.4 & 17.0 & 6.7 & 172.0 \\
\hline 17.04 .2002 & 9.0 & 10.3 & 13.0 & 2.2 & 2.6 & 22.4 & 68.5 & 0.4 & 64.6 & 16.0 & 6.7 & 171.0 \\
\hline 15.05 .2002 & 9.1 & 9.8 & 13.5 & 2.0 & 3.2 & 23.4 & 69.4 & 0.4 & 60.3 & 13.0 & 5.2 & 178.0 \\
\hline 13.06 .2002 & 9.9 & 8.2 & 12.4 & 2.1 & 3.5 & 21.1 & 69.4 & 0.4 & 66.3 & 16.0 & 6.5 & 178.0 \\
\hline 11.12.2002 & 13.5 & 6.1 & 13.9 & 3.3 & 3.2 & 22.0 & 70.2 & 0.4 & 68.9 & 12.0 & 6.7 & 174.0 \\
\hline 15.01.2003 & 8.8 & 9.7 & 12.7 & 2.3 & 4.2 & 27.2 & 69.4 & 0.4 & 68.4 & 13.0 & 7.5 & 177.0 \\
\hline 10.02 .2003 & 9.7 & 8.4 & 11.2 & 3.3 & 4.4 & 23.1 & 71.2 & 0.4 & 62.9 & 13.0 & 7.0 & 175.0 \\
\hline 12.03 .2003 & 10.5 & 7.8 & 12.4 & 2.2 & 3.6 & 22.6 & 70.7 & 0.5 & 55.3 & 13.0 & 7.5 & 175.0 \\
\hline 09.04 .2003 & 11.5 & 6.9 & 12.4 & 2.1 & 4.0 & 23.5 & 70.9 & 0.5 & 61.2 & 15.0 & 6.8 & 176.0 \\
\hline 17.05 .2003 & 10.4 & 7.7 & 11.7 & 2.3 & 3.4 & 23.2 & 69.7 & 0.4 & 63.7 & 15.0 & 6.8 & 177.0 \\
\hline Average & 9.9 & 8.7 & 12.6 & 2.4 & 3.5 & 23.4 & 69.9 & 0.4 & 65.0 & 14.7 & 6.7 & 176.1 \\
\hline$\sigma$ & 1.4 & 1.4 & 0.7 & 0.4 & 0.6 & 1.6 & 0.8 & 0.0 & 5.3 & 1.8 & 0.6 & 3.0 \\
\hline
\end{tabular}



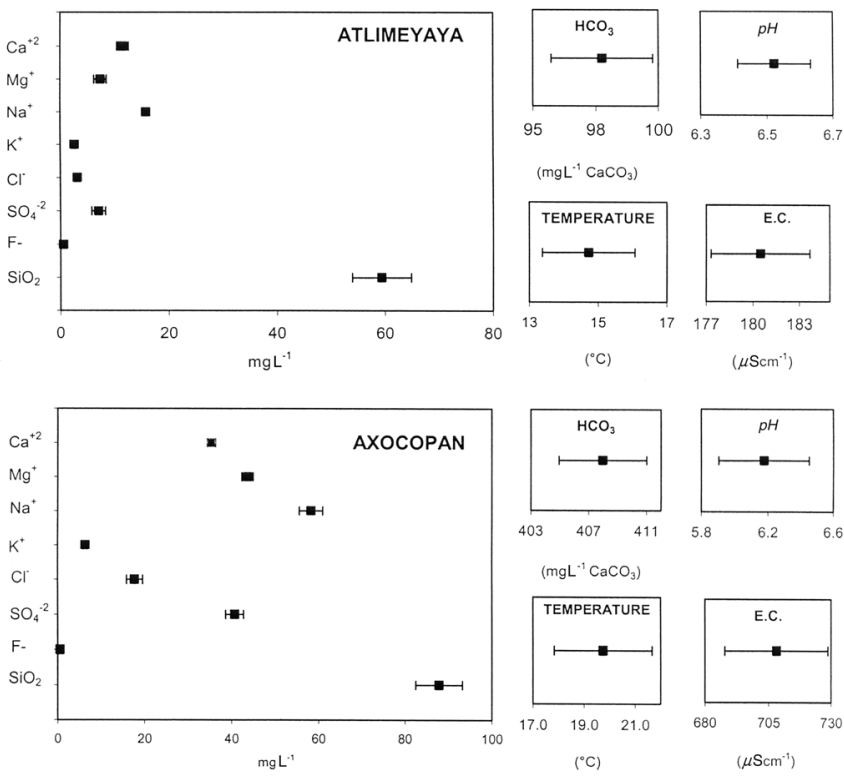

$\left(\mathrm{mgL}^{-1} \mathrm{CaCO}_{3}\right)$
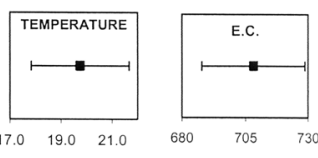

$\left({ }^{\circ} \mathrm{C}\right)$
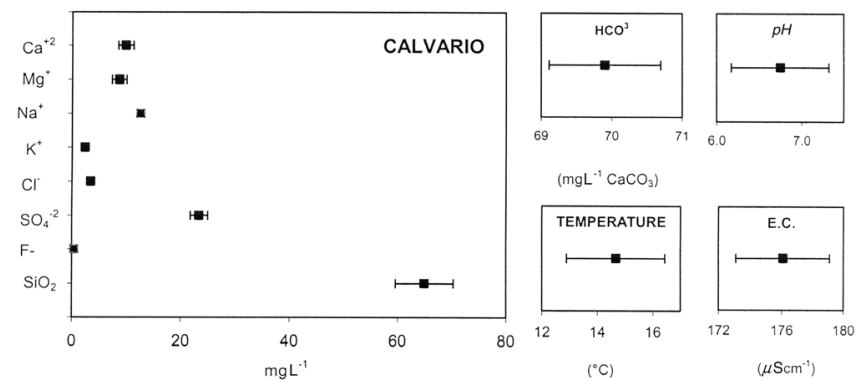

Fig. 5. Fluctuations in the physicochemical parameters at the Popocatepetl springs, Atlimeyaya, Axocopan and Calvario during 2002-2003. Concentration values in $\mathrm{mgL}^{-1}$, temperature in ${ }^{\circ} \mathrm{C}$ and conductivity (E.C.) in $\mu \mathrm{Scm}^{-1}$.

ity based on seismic behaviour. Panel d correspond to the number of long-period earthquakes per day, associated with the ascending motion of volcanic fluid through cracks or conduits.

The letters «e» and «E», located at the bottom of this panel, indicate the occurrence of small and large volcanic explosions, respectively. Panel e shows the volcano tectonic earthquakes, which are related to stress that fracture the rock, and are located under the Popocatepetl volcano and plotted versus depth, where the cero represents sea level. The size of the symbols is proportional to the magnitude of the earthquakes, which ranges from 1.5 to 3.8 . The number at the bottom of panel e corresponds to the number of volcano-tectonic earthquakes during each stage of activity.

Soil radon had its maximum peaks in correlation with the initial phase of the eruption, i.e. December 1994 at Tlamacas (panel a), and also, although not as intense (panel b), at Paso de Cortes (Segovia and Mena, 1999). Beginning on December, 1997, a large soil radon peak clearly stands out at Tlamacas, and it is correlated with the first explosions that partially destroyed a large $\left(\approx 12 \times 10^{6} \mathrm{~m}^{3}\right)$ lava dome, that obstructed the crater and probably produced an 

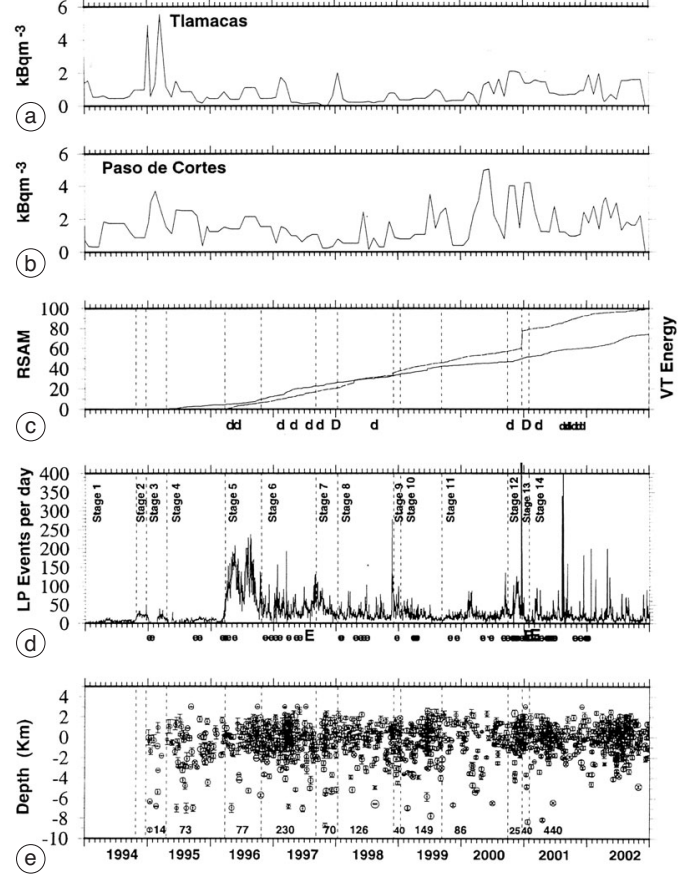

Fig. 6a-e. 1994-2002 soil radon and volcanic activity (see text): a) soil radon at Tlamacas; b) soil radon at Paso de Cortes; c) cumulative seismic energy from continuous ground vibration (solid line); cumulative energy released by the volcano-tectonic earthquakes (dashed line); d) number of long-period earthquakes per day; e) Volcano tectonic earthquakes under the Popocatepetl volcano versus depth (the cero represents sea level).

increase in the state of stress below the volcano edifice. Paso de Cortes did not show a clear correlation in radon with this volcanic event. Another episode of volcanic activity, consisting of frequent explosions that destroyed another lava dome, was observed on November-December, 1998, and a small radon increment can be observed at this time in both. Tlamacas and Paso de Cortes sites. The largest volcanic activity observed at Popocatepetl since 1994 and up to date, was observed in December 2000, and January 2001, when the largest dome was formed and the most explosive-dome-destruction occurred respectively. These events were preceded by a change in the seismic rate since Sep- tember, 2000. It is clear that the radon signals at both sites showed an increment by mid 2000, which probably corresponds with the preceding phase of volcanic activity observed months later. It is also clear, that the radon background level has kept a larger value since mid 2000, as compared to the values of the previous years.

Soil radon measurements at Popocatepetl have proved useful together with other volcano measurements, to characterize increments on the volcano activity.

\section{Acknowledgements}

The authors acknowledge S. Ceballos, D. Cruz, F. Montes, A. Aguayo, N. Ceniceros and O. Cruz for technical assistance. This study was carried out with partial financial support from CONACYT, Project 40858.

\section{REFERENCES}

APHA-AWWA-WPCF (American Public Health Association-American Water Works Association-Water Pollution Control Federation) (1995): Standard Methods for Examination of Water and Wastewater, edited by M.H. Franson and A.E. GREENBERG (APHA-AWWAWPCF, Washington D.C.), 19th edition.

CENAPRED (2003): http://www.prueba.cenapred.UNAM.mx

Cisniega, M.G., N. Segovia and N. LoPeZ (2002): Methodology for volatile organic compounds determination in water from wells and springs in Mexico state, Mexico, Geofís. Int., 41, 233-237.

De la Cruz-Reyna, S., J.L. Quezada, C. Peña, O. ZePeda and T. SANCHEZ (1995): Historia de la actividad reciente del Popocatepetl (1354-1995), in Volcan Popocatepetl. Estudios realizados durante la crisis de 19941995 (CENAPRED-UNAM, Mexico D.F.), 3-22.

Segovia, N. and M. Mena (1999): Soil radon pulses related to the initial phase of volcanic eruptions, $\mathrm{Nuovo} \mathrm{Ci}$ mento, 22C, 275-279

Segovia, N., C. Valdes, P. Peña, M. Mena and E. Tamez (2001): Soil radon response around an active volcano, Radiat. Meas., 34 (1), 433-436.

Segovia, N., M.A. Armienta, J.L. Seidel, M. Monnin, P. Peña, M.B.E. Lopez, M. Mena, C. Valdes, E. Tamez, R.N. LOPEZ and P. ARANDA (2002): Radon in soil and chemical composition of spring water near Popocatepetl volcano, Mexico, Geofís. Int., 41, 399-404.

VARLEY, N.R. and M.A. ARMIENTA (1999): Soil gas measurements as an indicator of volcanic activity at Popocatepetl, Mexico, Nuovo Cimento, 22C, 269-274.

VARLEY, N.R. and M.A. ARMIENTA (2001): The absence of diffuse degassing at Popocateptl volcano, Mexico, Chem. Geol., 177, 157-173. 